\title{
Front Matter: Volume 6587
}

, "Front Matter: Volume 6587," Proc. SPIE 6587, Liquid Crystals and Applications in Optics, 658701 (23 May 2007); doi: 10.1117/12.745422

SPIE Event: International Congress on Optics and Optoelectronics, 2007, Prague, Czech Republic 


\title{
PROCEEDINGS OF SPIE
}

\section{Liquid Crystals and Applications in Optics}

\author{
Milada Glogarova \\ Peter Palffy-Muhoray \\ Martin Copic \\ Editors
}

17-18 April 2007

Prague, Czech Republic

Sponsored by

SPIE Europe

Cooperating Organizations

SPIE Czech Republic Chapter

COST

ESF-European Science Foundation (France)

Czech and Slovak Society for Photonics

ePIXnet (Belgium)

Fyzikálni Ústav (Czech Republic)

Meta Morphose (United Kingdom)

NEMO—Network of Excellence in Micro-Optics (Belgium)

Phoremost

SPIE Poland Chapter

Published by

SPIE 
The papers included in this volume were part of the technical conference cited on the cover and title page. Papers were selected and subject to review by the editors and conference program committee. Some conference presentations may not be available for publication. The papers published in these proceedings reflect the work and thoughts of the authors and are published herein as submitted. The publisher is not responsible for the validity of the information or for any outcomes resulting from reliance thereon.

Please use the following format to cite material from this book:

Author(s), "Title of Paper," in Liquid Crystals and Applications in Optics, edited by Milada Glogarova, Peter Palffy-Muhoray, Martin Copic, Proceedings of SPIE Vol. 6587 (SPIE, Bellingham, WA, 2007) Article CID Number.

ISSN 0277-786X

ISBN 9780819467157

Published by

SPIE-The International Society for Optical Engineering

P.O. Box 10, Bellingham, Washington 98227-0010 USA

Telephone 1 360/676-3290 (Pacific Time) · Fax 1 360/647-1445

http://www.spie.org

Copyright (c) 2007, Society of Photo-Optical Instrumentation Engineers

Copying of material in this book for internal or personal use, or for the internal or personal use of specific clients, beyond the fair use provisions granted by the U.S. Copyright Law is authorized by SPIE subject to payment of copying fees. The Transactional Reporting Service base fee for this volume is \$18.00 per article (or portion thereof), which should be paid directly to the Copyright Clearance Center (CCC), 222 Rosewood Drive, Danvers, MA 01923. Payment may also be made electronically through CCC Online at http://www.copyright.com. Other copying for republication, resale, advertising or promotion, or any form of systematic or multiple reproduction of any material in this book is prohibited except with permission in writing from the publisher. The CCC fee code is 0277 $786 \times / 07 / \$ 18.00$.

Printed in the United States of America.

Publication of record for individual papers is online in the SPIE Digital Library.

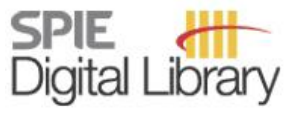

SPIEDigitalLibrary.org

Pagination: Proceedings of SPIE follow an e-First publication model, with papers published first online and then in print and on CD-ROM. Papers are published as they are submitted and meet publication criteria. A unique, consistent, permanent citation identifier (CID) number is assigned to each article at the time of the first publication. Utilization of CIDs allows articles to be fully citable as soon they are published online, and connects the same identifier to all online, print, and electronic versions of the publication. SPIE uses a six-digit CID article numbering system in which:

- The first four digits correspond to the SPIE volume number.

- The last two digits indicate publication order within the volume using a Base 36 numbering system employing both numerals and letters. These two-number sets start with 00, 01, 02, 03, 04, 05, 06, 07 , 08, 09, OA, OB ... OZ, followed by 10-1Z, 20-2Z, etc.

The CID number appears on each page of the manuscript. The complete citation is used on the first page, and an abbreviated version on subsequent pages. 


\title{
Contents
}

\author{
ix Conference Committee
}

xi Introduction

\section{PLENARY SESSION}

658702 Liquid crystalline nonlinear optical metamaterials with low-loss tunable negative-zeropositive refractive indices [6587-203] (Plenary Paper)

I. C. Khoo, A. Diaz, D.-H. Kwon, D. H. Werner, The Pennsylvania State Univ. (USA)

\section{SESSION 1 PHOTONICS I}

658704 Self-assembly in nematic colloids (Invited Paper) [6587-02]

I. Muševič, J. Stefan Institute (Slovenia) and Univ. of Ljubljana (Slovenia); M. Škarabot, J. Stefan Institute (Slovenia); M. Ravnik, Univ. of Ljubljana (Slovenia); U. Tkalec, J. Stefan Institute (Slovenia); I. Poberaj, D. Babič, Univ. of Ljubljana (Slovenia); S. Žumer, J. Stefan Institute (Slovenia) and Univ. of Ljubljana (Slovenia)

658705 Spectral properties of photonic liquid crystal fibers [6587-03]

T. R. Woliński, A. Czapla, S. Ertman, A. W. Domański, Warsaw Univ. of Technology (Poland);

J. Wójcik, Maria Curie Sklodowska Univ. (Poland); R. Dąbrowski, Military Univ. of Technology (Poland)

658706 Liquid crystal molecular orientation in photonic liquid crystal fibers with photopolymer layers [6587-04]

S. Ertman, T. R. Woliński, A. Czapla, K. Nowecka, Warsaw Univ. of Technology (Poland); E. Nowinowski-Kruszelnicki, Military Univ. of Technology (Poland); J. Wójcik, Maria Curie Sklodowska Univ. (Poland)

\section{SESSION 2 PHOTONICS II}

658707 Photochemical manipulation of colloidal structures in liquid-crystal colloids (Invited Paper) [6587-05]

T. Yamamoto, Nanotechnology Research Institute, National Institute of Advanced Industrial Science and Technology (Japan) and Japan Science and Technology Agency (Japan);

Y. Tabe, Japan Science and Technology Agency (Japan) and Waseda Univ. (Japan);

H. Yokoyama, Nanotechnology Research Institute, National Institute of Advanced Industrial Science and Technology (Japan) and Japan Science and Technology Agency (Japan)

658708 Rotating light with light: generation of helical modes of light by spin-to-orbital angular momentum conversion in inhomogeneous liquid crystals (Invited Paper) [6587-06]

L. Marrucci, Univ. degli Studi di Napoli Federico II, CNR-INFM (Italy) 
658709 Theoretical modeling of heterogeneous LC systems: nano-suspensions and polymer stabilized LC lens (Invited Paper) [6587-07]

V. Yu. Reshetnyak, S. M. Shelestiuk, S. L. Subota, S. Pavliuchenko, National Taras

Shevchenko Univ. of Kyiv (Ukraine); T. J. Sluckin, Univ. of Southampton (United Kingdom)

\section{SESSION 3 PHOTONICS III}

65870D Characterisation of liquid crystals for broadband optimal design of Mueller matrix ellipsometers [6587-11]

J. Ladstein, M. Kildemo, G. K. Svendsen, I. S. Nerbø, F. Stabo-Eeg, Norwegian Univ. of

Science and Technology (Norway)

65870E Electrically controlled depolarization of light by use of liquid crystal cells [6587-12]

A. W. Domański, D. Budaszewski, M. Sierakowski, T. R. Woliński, Warsaw Univ. of Technology

(Poland)

\section{SESSION 4 HOLOGRAPHY AND GRATING}

65870F Neutron diffraction from holographic polymer-dispersed liquid crystals (Invited Paper) [6587-13]

I. Drevensek-Olenik, Univ. of Ljubljana (Slovenia); M. A. Ellabban, M. Fally, Univ. of Vienna

(Austria); K. P. Pranzas, J. Vollbrandt, GKSS Research Ctr. (Germany)

$65870 G$ Organic and hybrid tunable Bragg gratings for photonic devices (Invited Paper) [6587-14] G. Abbate, CNR-INFM, Univ. degli Studi di Napoli Federico II (Italy); A. Marino, INFM, Univ. degli Studi di Napoli Federico II (Italy); V. Tkachenko, Consiglio Nazionale delle Ricerche (Italy); F. Vita, Università Politecnica delle Marche (Italy)

$65870 \mathrm{H} \quad 100 \mathrm{GHz}$ electrically tunable planar Bragg grating via nematic liquid crystal overlay for reconfigurable WDM networks. [6587-15]

F. R. Mahamd Adikan, J. C. Gates, A. Dyadyashu, H. E. Major, C. B. E. Gawith, M. Kaczmarek, Univ. of Southampton (United Kingdom); I. J. G. Sparrow, Stratophase Ltd. (United Kingdom); P. G. R. Smith, Univ. of Southampton (United Kingdom)

658701 High-performance rewritable Bragg hologram with high multiplicities [6587-16]

A. Shishido, T. Ikeda, Tokyo Institute of Technology (Japan)

65870J Optimization of a holographic memory setup using a LCD and a PVA based photopolymer [6587-17]

E. Fernández, M. Ortuño, A. Márquez, S. Gallego, A. Beléndez, I. Pascual, Univ. de Alicante (Spain)

\section{SESSION $5 \quad$ NONLINEAR EFFECTS AND LASING I}

65870K Nonlinear wave guiding in nematic liquid crystals (Invited Paper) [6587-18]

J. Beeckman, K. Neyts, Ghent Univ. (Belgium); X. Hutsebaut, M. Haelterman, Univ. libre de Bruxelles (Belgium) 
$65870 \mathrm{M}$ Discrete X-wave-like spatio-temporal structures in one-dimensional nonlinear liquid crystal waveguide arrays [6587-20]

G. Papazisimos, L. Halastanis, S. Droulias, Y. Kominis, P. Papagiannis, K. Hizanidis, National Technical Univ. of Athens (Greece)

65870N Spatiotemporal pattern formation in slab nematic liquid crystal cells [6587-21]

P. Papagiannis, L. Halastanis, G. Papazisimos, N. Moshonas, S. Droulias, Y. Kominis,

K. Hizanidis, National Technical Univ. of Athens (Greece)

\section{SESSION $6 \quad$ NONLINEAR EFFECTS AND LASING II}

65870P Random lasing in dye doped nematic liquid crystals: the role of confinement geometry [6587-23]

G. Strangi, S. Ferjani, V. Barna, A. De Luca, C. Versace, N. Scaramuzza, R. Bartolino, CNRINFM, Univ. of Calabria (Italy)

65870Q Random lasing in a bistable smectic A liquid crystal [6587-24]

S. M. Morris, A. D. Ford, D. J. Gardiner, H. J. Coles, Univ. of Cambridge (United Kingdom)

$65870 R$ Dynamics of the photoexictation of azo dye-doped liquid crystals probing by pumped attenuated total reflection [6587-25]

K. Y. Lo, C. Y. Huang, National Chia Yi Univ. (Taiwan)

\section{SESSION 7 POLYMER AND POLYMER DISPERSED MATERIALS}

65870T Photo-enhanced performance and photo-tunable degradation in LC ecopolymers (Invited Paper) [6587-27]

T. Kaneko, Japan Advanced Institute of Science and Technology (Japan)

\section{SESSION 8 DEVICES}

65870W Spatial filters based on azo-dye-doped liquid crystal films [6587-30]

A. Y.-G. Fuh, T.-H. Lin, National Cheng Kung Univ. (Taiwan)

65870X Multi-colour switching of polymer stabilized chiral nematic liquid crystal devices [6587-31]

J. Chen, S. M. Morris, T. D. Wilkinson, H. J. Coles, Univ. of Cambridge (United Kingdom)

\section{POSTER SESSION}

658710 Simplified approximation of an elastic free energy density of smectic $B_{2}$-phase of bentshaped molecules [6587-34]

L. Lejček, Institute of Physics (Czech Republic)

658711 Macroscopic birefringence in liquid crystals from novel cyanobacterial polysaccharide with an extremely high molecular weight [6587-36]

M. Okajima-Kaneko, Japan Advanced Institute of Science and Technology (Japan);

D. Hayasaka-Kaneko, The Univ. of Tokyo (Japan); S. Miyazato, T. Kaneko, Japan Advanced Institute of Science and Technology (Japan) 
658712 Liquid crystal displays with high brightness of visualization versus active displays [6587-37] M. Olifierczuk, J. Zieliński, Military Univ. of Technology (Poland)

658714 Fabry-Perot liquid crystal tunable filter for interrogation of multiple Fibre Bragg grating sensors [6587-39]

Y. Semenova, G. Farrell, G. Rajan, Dublin Institute of Technology (Ireland)

658715 Characterization and optimization of liquid crystal displays for data storage applications [6587-40]

A. Márquez, S. Gallego, D. Méndez, M. L. Álvarez, E. Fernández, M. Ortuño, A. Beléndez, I. Pascual, Univ. de Alicante (Spain)

658716 Low-cost liquid crystal display optimized as a monopixel coherent modulator [6587-41] A. Márquez, M. L. Álvarez, L. A. Puerta, R. Estévez, E. Fernández, A. Beléndez, I. Pascual, Univ. de Alicante (Spain)

658719 Temperature control molecular stacking of discotic liquid crystal in columnar mesophase [6587-44]

W. Zheng, C.-Y. Chiang, C. W. Ong, S.-C. Liao, J.-Y. Huang, National Sun Yat-Sen Univ.

(Taiwan)

65871 B Determination of the Jones matrix of an LC cell and derivation of the physical parameters of the LC molecules [6587-46]

A. Hermerschmidt, Holoeye Photonics AG (Germany); S. Quiram, F. Kallmeyer, H. J. Eichler, Technische Univ. Berlin (Germany)

65871D Application of an optimized low-cost spatial light modulator for efficient compensation of eye aberration patterns [6587-48]

V. Durán-Bosch, V. Climent, E. Tajahuerce, J. Lancis, Univ. Jaume I (Spain); Z. Jaroszewicz, Institute of Applied Optics (Poland) and National Institute of Telecommunications (Poland); J. Arines, S. Bará, Univ. de Santiago de Compostela (Spain)

$65871 \mathrm{E}$ Optimization of the phase-modulation response of a TNLCD by means of a method based on Poincaré sphere [6587-49]

V. Durán-Bosch, J. Lancis, E. Tajahuerce, M. Fernández-Alonso, G. Mínguez-Vega,

L. Martínez-León, V. Torres-Company, Univ. Jaume I (Spain)

$65871 \mathrm{~F}$ Dynamic behaviour of ferro-electric liquid crystal by means of nuclear magnetic resonance and dielectric spectroscopy [6587-50]

V. Domenici, Jožef Stefan Institute (Slovenia) and Univ. degli studi di Pisa (Italy); A. Marini, Univ. degli studi di Pisa (Italy) and Scuola Normale Superiore di Pisa (Italy); R. Menicagli, C. A. Veracini, Univ. degli studi di Pisa (Italy); A. M. Bubnov, M. Glogarova, Institute of Physics (Czech Republic)

$65871 \mathrm{G}$ High-solubility liquid crystal dye guest host device [6587-51]

D. J. Gardiner, H. J. Coles, Univ. of Cambridge (United Kingdom)

$65871 \mathrm{H}$ Second-harmonic generation studies in the SmCP phase of bent-shaped mesogens [6587-52]

V. Novotná, J. Kroupa, M. Kašpar, M. Glogarová, V. Hamplová, Institute of Physics (Czech Republic) 
658711 A comparison of the flexoelectro-optic effect in the uniform lying helix and standing helix geometries [6587-53]

S. M. Morris, F. Castles, B. J. Broughton, H. J. Coles, Univ. of Cambridge (United Kingdom)

$65871 \mathrm{~J}$ Role of optical extinction in holographic polymer-dispersed liquid crystals [6587-54]

M. A. Ellabban, Univ. of Vienna (Austria) and Tanta Univ. (Egypt); M. Bichler, M. Fally, Univ. of Vienna (Austria); I. Drevensek-Olenik, Univ. of Ljubljana (Slovenia)

Author Index 
Downloaded From: https://www.spiedigitallibrary.org/conference-proceedings-of-spie on 26 Apr 2023

Terms of Use: https://www.spiedigitallibrary.org/terms-of-use 


\title{
Conference Committee
}

\author{
Symposium Chairs \\ Pavel Tománek, Brno University of Technology (Czech Republic) \\ Miroslav Hrabovský, Palacký University (Czech Republic) \\ Hugo Thienpont, Vrije Universiteit Belgium \\ Symposium Honorary Chair \\ Karel Jungwirth, Institute of Physics (Czech Republic) \\ Conference Chairs \\ Milada Glogarova, Institute of Physics (Czech Republic) \\ Peter Palffy-Muhoray, Kent State University (USA) \\ Martin Copic, University of Ljubljani (Slovenia)
}

Program Committee

Andy Y.-G. Fuh, National Cheng Kung University (Taiwan)

Lubor Lejček, Institute of Physics (Czech Republic)

Kristiaan Neyts, Ghent University (Belgium)

Yuri A. Reznikov, Institute of Physics (Ukraine)

Valery P. Shibaev, M.V. Lomonosov Moscow State University (Russia)

Atsushi Shishido, Tokyo Institute of Technology (Japan)

Hideo Takezoe, Tokyo Institute of Technology (Japan)

Session Chairs

1 Photonics I

Noel A. Clark, University of Colorado, Boulder (USA)

2 Photonics II

Tomasz R. Wolinksi, Warsaw University of Technology (Poland)

3 Photonics III

Milada Glogarova, Institute of Physics (Czech Republic)

$4 \quad$ Holography and Grating

Igor Muševič, Jožef Stefan Institute (Slovenia)

$5 \quad$ Nonlinear Effects and Lasing I

Giancarlo Abbate, Università degli Studi di Napoli Federico II, CNR-INFM (Italy) 
$6 \quad$ Nonlinear Effects and Lasing II

Michel Mitov, Centre National de la Recherche Scientifique-CEMES (France)

$7 \quad$ Polymer and Polymer Dispersed Materials

Viktor Yu. Reshetnyak, National Taras Shevchencko University of Kyiv (Ukraine)

8 Devices

Peter Palffy-Muhoray, Kent State University (USA) 


\section{Introduction}

This SPIE volume includes the contributions presented at the conference on Liquid Crystals and their Applications in Optics held within the SPIE International Congress on Optics and Optoelectronics (ICOO), which took place in Prague in April 2007. The previous ICOO organized in Central and Eastern Europe was located in Warsaw in 2005.

The conference covered a vast range of topics, namely photonics, holography, gratings, lasing, nonlinear effects, wave guiding, negative index liquid crystalline materials, photonics of self-assembly colloids, membranes, nanocomposites, and liquid crystal fibers.

The best specialists were invited to present 14 keynote lectures in the mentioned fields; in addition, 18 selected oral contributions and 22 posters were presented. Most of the manuscripts of presented contributions are published in this volume, giving an adequate overview of current research on optical applications of liquid crystals.

In their free time, participants could enjoy historical monuments of Prague and its thousand-year history. Prague is also interesting because of its rich history in physics. The outstanding personalities who stayed in Prague are represented in historical succession: Johanes Kepler, Christian Doppler, Ernst Mach, and Albert Einstein. For the liquid crystal community it is surely interesting that about 120 years ago the liquid crystalline properties were discovered in Prague by Fridrich Reinitzer, a professor at the Imperial Institute for Plant Physiology at the German University in Prague. He published his results in Monatshefte für Chemie, Vol. 9, 421-441, 1888.

Milada Glogarova

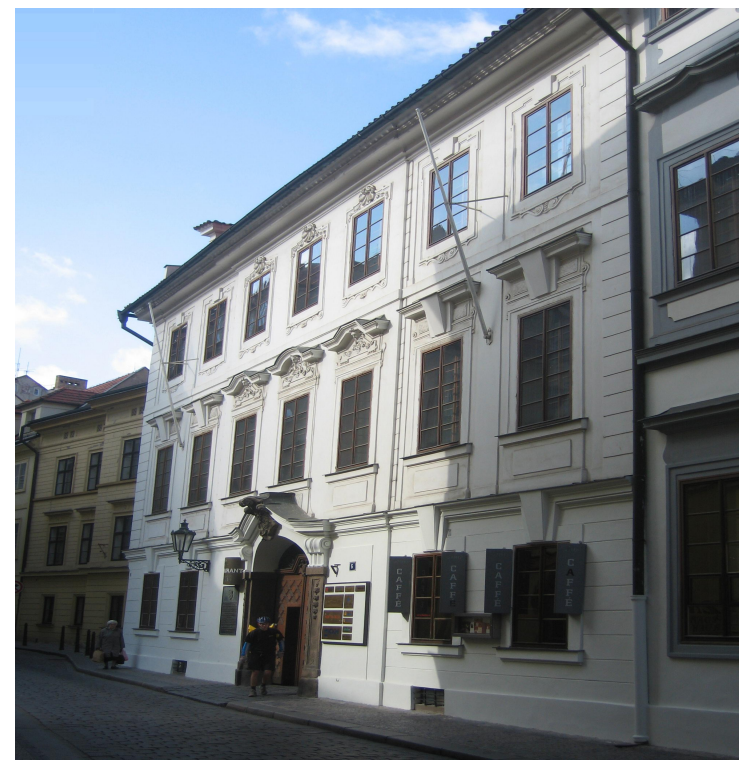

The house of the former German Technical University situated in Husova street, Prague Old Town, where F. Reinitzer discovered liquid crystalline properties on cholesteryl acetate. 